\title{
PEMANFAATAN MULTIMEDIA UNTUK PEMBELAJARAN SAINS \\ PADA SISWA TAMAN KANAK-KANAK ALQUR'AN (TKQ) DARUL ULUM JABON MEKAR, PARUNG, BOGOR
}

\section{THE UTILIZATION OF MULTIMEDIA FOR SCIENCE LEARNING IN ALQUR'AN KINDERGARTEN (TKQ) DARUL ULUM STUDENTS JABON MEKAR, PARUNG, BOGOR}

\author{
Subekti Nurmawati ${ }^{1)}$, Heny Kurniawati ${ }^{2)}$, Inggit Winarni ${ }^{3)}$, Budi Prasetyo ${ }^{4)}$ \\ ${ }^{1,2,3,4}$ Program Studi Biologi, Jurusan MIPA, Fakultas Sains dan Teknologi, UT \\ ${ }^{1}$ Email: nurma@ecampus.ut.ac.id
}

\begin{abstract}
Abstrak: Taman kanak-kanak Alqur'an (TKQ) Darul Ulum Jabon Mekar adalah lembaga pendidikan yang berbasis pada sistem pembelajaran islami. Lembaga pendidikan tersebut telah meluluskan sebanyak 243 siswa/i dengan berbagai prestasi yang membanggakan. Namun demikian kompetensi guru dalam pengajaran sains bagi siswa usia taman kanak-kanak masih dirasa kurang dan sarana maupun prasarana yang belum memadai untuk mendukung pembelajan sains.Untuk itu perlu dilakukan kegiatan program Pengabdian kepada Masyarakat tentang pemberian materi pelatihan dan praktek kepada para guru berkaitan dengan metode pengajaran sains yang tepat bagi anak-anak TKQ Darul Ulum Jabon Mekar. Tujuan kegiatan PkM meliputi a). mengidentifikasi kebutuhan dan menyiapkan materi multimedia untuk pengajaran tentang sains; b). memberikan pelatihan, pendampingan, dan monitoring kepada para guru dalam pengajaran sains melalui pemanfaatan multimedia; dan c). melibatkan siswa dalam proses pengajaran sains sederhana yang disampaikan oleh guru dengan memanfaatkan multimedia. Metode pelaksanaan meliputi: a). persiapan; b). pelatihan; c). pendampingan; d). monitoring; dan e). evaluasi. Seluruh rangkaian kegiatan pelatihan telah dilaksanakan sehingga proses pembelajaran materi sains di ruang kelas berjalan lancar dan normal, terjadi interaksi dua arah antara para guru dan siswa/i yang dapat menciptakan suasana belajar cukup ideal.
\end{abstract}

Kata kunci: Multimedia, Islami, PkM, Pelatihan, Praktek.

Abstract: Alquran Kindergarten (TKQ) Darul Ulum Jabon Mekar is an educational institution based on the Islamic learning system. This educational institution has graduated 243 students with various proud achievements. However, teacher competence in teaching science for kindergarten-age students is still lacking and the facilities and infrastructure are inadequate to support science learning. For this reason, it is necessary to carry out Community Service program activities regarding the provision of training and practical materials to related teachers. with appropriate science teaching methods for TKQ Darul Ulum Jabon Mekar children. The objectives of PkM activities include a). identify needs and 
prepare multimedia materials for teaching about science; b). provide training, mentoring, and monitoring to teachers in science teaching through the use of multimedia; and c). involving students in the simple science teaching process delivered by the teacher by utilizing multimedia. Implementation methods include: a). preparation; b). training; c). accompaniment; d). monitoring, and e). evaluation. A whole series of training activities have been carried out so that the learning process of science material in the classroom runs smoothly and normally, there is a two-way interaction between teachers and students which can create an ideal learning atmosphere.

Keywords: multimedia, Islamic, PkM, training, practice.

\section{PENDAHULUAN}

Taman Kanak-kanak Al-qur'an (TKQ) Darul UlumJabon Mekar yang berlokasi di Perumahan Universitas Terbuka (UT) Desa Jabon Mekar, Parung didirikan pada tahun 2008 atas dasar pertimbangan semakin meningkatnya jumlah anak-anak usia pra sekolah di sekitar perumahan.TKQ Darul Ulum Jabon Mekar tersebut merupakan tempat penyelenggaraan pendidikan bagi para siswa/i yang berasal dari keluarga kurang mampu.

Para orang tua murid yang tinggal di sekitar perumahan berkeinginan kuat untuk menyekolahkan putra-putrinya pada lembaga pendidikan yang berorientasi pada penguatan pendidikan agama Islam, pembentukan karakter, dan pembentukan kepribadian yang sholeh/sholehah. Selain itu, mereka juga mengharapkan besaran biaya pendidikan yang dibebankannya dapat terjangkau, bahkan beberapa murid dibebaskan dari kewajiban membayar SPP karena tidak mampu membayar. Berasumsi dari fenomena ini maka dirasa perlu untuk menyelenggarakan lembaga pendidikan yang berbasis islami, serta membekali anak dengan karakter akhlaqul karimah.

Selama kurun waktu 10 (sepuluh) tahun sejak mulai menerima siswa baru, TKQ Darul Ulum telah meluluskan sebanyak 243 siswa/i. Selama kurun waktu itu pula, proses belajar mengajar dilakukan di lokasi serambi Masjid Darul Ulum Perumahan Universitas Terbuka, Desa Jabon Mekar, Parung. TKQ Darul Ulum tersebut menempati ruangan seluas kurang lebih $50 \mathrm{~m} 2$ yang terbagi menjadi dua kelas A dan kelas B, dengan fasilitas apa adanya. Tentu, kondisi tersebut sangatlah tidak memadai bagi sebuah ruangan kelas. Di dunia pendidikan, secara 
aspek legalitas hukum agar kiprah TKQ Darul Ulum dapat diakui sebagai lembaga pendidikan yang berbasis islami, maka mulai tahun 2018 sistem pengelolaannya ada di bawah naungan Yayasan Darul Ulum Jabon Mekar.

Proses belajar mengajar pada TKQ Darul Ulum mengikuti standar mutu pendidikan TKQ umumnya, yang meliputi lingkup pengajaran pokok dan muatan lokal. Lingkup pengajaran pokok meliputi: hafalan bacaan sholat, hafalan surat pendek, latihan praktek ibadah, doa dan adab harian, serta pengenalan dasar dinul Islam. Semua materi yang disajikan disesuaikan dengan perkembangan anak usia pra sekolah, yaitu melalui berbagai permainan yang menyenangkan sehingga tidak membosankan. Adapun lingkup pengajaran muatan lokal disesuaikan dengan kebutuhan dan kondisi setempat, yang selanjutnya dikembangkan dalam bentuk tema dan sub-tema.

Secara eksplisit mata pelajaran sains memang tidak tercantum di dalam kurikulum tingkatan TK, namun begitu bukan berarti bahwa pelajaran sains tidak ada sama sekali di TK (Dewi, 2012). Materi pelajaran Sains di TK tetap ada dan terpadu dengan bidang mata pelajaran lainnya, bahkan disajikan hampir di setiap tema pembelajaran. Pengenalan sains untuk anak TK jika dilakukan dengan benar akan mengembangkan secara bertahap kemampuan berpikir logis yang belum dimiliki anak (Suyanto, 2014). Semiawan dalam (Asiah, 2012) mengemukakan bahwa keterampilan proses adalah keterampilan ilmiah yang mencakup keterampilan kognitif, psikomotor, dan afektif. Diharapkan dengan memanfaatkan multimedia anak-anak TKQ Darul Ulum Jabon Mekar dapat terangsang pikiran, perasaan, perhatian, dan minat keingintahuannya sehingga dapat lebih mudah memahami pembelajaran terkait sains.

Tujuan kegiatan Abdimas ( $\mathrm{PkM})$ ini memberikan pelatihan, pendampingan, dan monitoring kepada para guru dalam pengajaran sains melalui pemanfaatan multimedia. Selain itu, juga bertujuan mengikutsertakan siswa dalam proses pengajaran sains sederhana yang disampaikan oleh guru dengan memanfaatkan multimedia. Manfaat (luaran) yang diperoleh melalui pembelajaran sains menggunakan peralatan multimedia, siswa dapat melihat secara visual sehingga memiliki pengalaman yang cukup menarik dan melekat erat pada memorinya. 
Lebih lanjut pola berfikir siswa usia dini tersebut akan tercipta pemahaman dan imajinasi yang bagus, kritis, kreatif, dan berani dalam mengemukakan pendapatnya. Surasmi (2016) menyatakan penggunaan multimedia dalam pembelajaran adalah suatu upaya untuk menciptakan suasana belajar kreatif dan inovatif tanpa mengurangi tujuan belajar yang sesungguhnya yaitu adanya perubahan tingkah laku siswa yang dapat diukur dan diamati. Melalui kegiatan PkM ini sekolah TKQ Darul Ulum mendapatkan tambahan aset sarana pendidikan, berupa berbagai alat pembelajaran multimedia yang dapat dimanfaatkan untuk kegiatan pembalajaran siswa.

\section{METODE}

Tim PkM Prodi Biologi, FST-UT melakukan inventarisasi beberapa kegiatan dalam rangka pelaksanaan pelatihan keterampilan dan edukasi tentang pemanfaatan multimedia untuk pembelajaran sains pada siswa TKQ Darul Ulum di Perumahan UT Desa Jabon Mekar, Parung yang meliputi:

1. Persiapan.

Beberapa kegiatan yang menjadi awal pelaksanaankegiatan pelatihan \&edukasi adalah:

a) melakukan observasi tentang analisis kebutuhan melalui wawancara langsung kepada Kepsek dan para guru untuk mendapatkan informasi terkait kendala (hambatan) yang terjadi dalam pengajaran sains.

b) menyusun materi pelatihan tentang strategi pengajaran sains yang tepat pada anak-anak TKQ Darul Ulum yang berasal dari berbagai sumber rujukan.

c) mengadakan dan mempersiapkan beragam peralatan multimudia yang relevan dan mendukung praktek pembelajaran sains bagi anak-anak TKQ Darul Ulum.

2. Pelatihan.

Melalui pemberian materi pelatihan kepada para guru tentang metode pengajaran sains yang tepat bagi anak-anak TKQ Darul Ulum, berikut cara mempraktekkan penggunaan alat multimedia. 
3. Pendampingan.

Tahap pendampingan terhadap para guru di ruang kelas, dilakukan untuk memastikan metode yang diperoleh pada saat pelatihan telah sesuai ketika diterapkan pada anak-anak TKQ Darul Ulum pada saat belajar sains.

4. Monitoring.

Dilakukan dengan mengembangkanperangkat kuesioner melalui wawancara sehingga dapat mengukur ketercapaian kegiatanPkM. Kegiatan ini dilakukan pada saat proses pengajaran sedang berlangsung.

5. Evaluasi

Dilakukan di akhir seluruh rangkaian kegiatan PkM, dengan tujuan untuk mengetahui sejauh mana kegiatan tersebut telah dilaksanakan yang dituangkan di dalam laporan PkM.

\section{HASIL DAN PEMBAHASAN}

Hasil kegiatan observasi ke lokasi PkM di Perumahan UT Desa Jabon Mekar di antaranya:

a) Telah dirumuskan cara penyampaian materi yang relatif tepat bagi para guru untuk pembelajaran sains pada anak-anak pra-sekolah TKQ Darul Ulum. Cara yang dimaksud berupa penyajian contoh animasi, video, gambar visual yang mudah dipahami dalam kehidupan sehari-hari, seperti proses terjadinya hujan, kekayaan alam Indonesia berupa hutan, laut, dan sawah, serta proses metamorfosispada kupu-kupu dan katak. animasi digunakan dalam media pembelajaran untuk menarik perhatian siswa dan memperkuat motivasi serta sebagai sarana untuk memberikan pemahaman kepada murid atas materi yang akan diberikan (Utami, 2011).

b) Telah dicatat data sarana multimedia yang diperlukan untuk menunjang pembelajaran sains bagi siswa/i TKQ Darul Ulum berupa laptop, LCD, layar (screen), speaker, flashdisk, dan modem. Laptop digunakan sebagai tempat menyimpan file data yang diperlukan dan mengoperasikan program (software) multimedia untuk pembelajaran siswa. LCD, screen, dan speaker merupakan media yang digunakan untuk menyampaikan (memvisualkan) video, animasi 
atau gambar berbasis sains sehingga para siswa/i dapat melihat secara kasat mata serta mendengarkannya dengan jelas. Flashdisk (eksternal) dimanfaatkan untuk tempat menyimpan file-file contoh video maupun animasi yang diperlukan saat pembelajaran. Modem digunakan untuk browsing (berselancar) mencari konten tentang sains di internet secara leluasa.

Selanjutnya pada kegiatan pelatihan, beberapa guru secara bergantian menyampaikan materi sains dengan cara mengoperasikan laptop yang telah terkoneksi dengan layar $L C D$. Seluruh siswa-siswi TKQ Darul Ulum dengan tenang dan penuh konsentrasi menatap layar LCD yang disajikan di depan kelas. Para guru dengan tetap memperhatikan siswa-siswinya agar tetap tenang dan berkonsentrasi, sesekali mereka menjelaskan materi sains yang sedang divisualkan agar mudah dipahami. Beberapa contoh materi sains yang disajikan seperti proses terjadinya hujan mulai dari penguapan air laut oleh sinar matahari menjadi awan hingga sampai turunnya hujan. Sajian materi ini dikemas dalam bentuk animasi (Gambar 1). Tujuan penyampaian materi ini agar para siswa/i memahami benar proses terjadinya hujan sehingga pada saat mereka kehujanan atau sedang bermain air hujan, atau ketika melihat hujan turun akan teringat kuat di memori mereka proses terjadinya hujan tersebut.

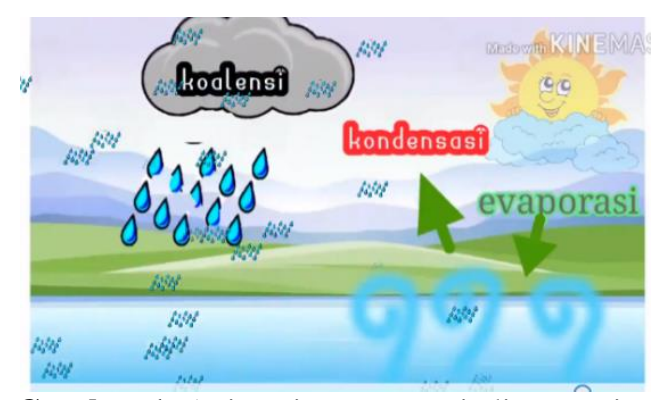

Gambar 1. Animasi Proses Terjadinya Hujan (Sumber:www.youtube.com)

Contoh penyajian materi sains yang lain adalah visualisasi tentang kekayaan alam Indonesia berupa hutan, laut, sawah, dan bentuk ekosistem lainnya yang dikemas dalam bentuk video (Gambar 2). Tujuan penyampaian materi ini agar para siswa/i memahami dan teringat bahwa seluruh kekayaan alam tersebut diciptakan atas kebesaran Allah S.W.T sehingga wajib disyukuri, dipelajari, dan dijaga kelestariannya. 


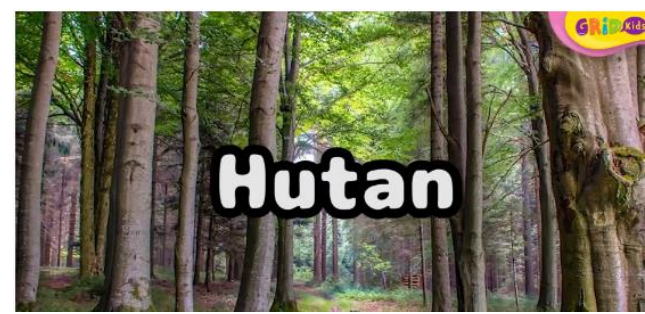

Gambar 2. Video Kekayaan Alam Indonesia (Sumber: www.youtube.com)

Contoh penyajian materi sains berikutnya adalah proses terjadinya metamorfosis (perubahan bentuk penampilan hewan) pada kupu-kupu dan katak. Materi ini dikemas dalam bentuk animasi, gambar, dan audio/suara (Gambar 3, 4, dan 5). Tujuan penyampaian materi ini agar para siswa/i memahami dengan benar dan mampu mengingat bahwa proses terbentuknya kupu-kupu yang mereka lihat saat bermain di halaman rumah berasal dari telur yang terus berkembang menjadi larva dan tumbuh berkembang lagi menjadi pupa, yang terakhir dari pupa berkembang menjadi kupu-kupu kecil.

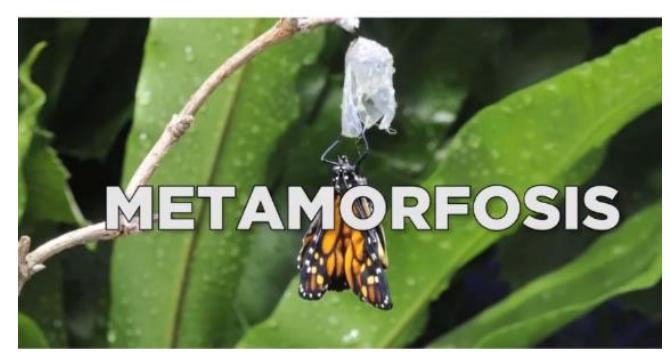

Gambar 3. Video Metamorfosis Kupu-kupu (Sumber: www.youtube.com)

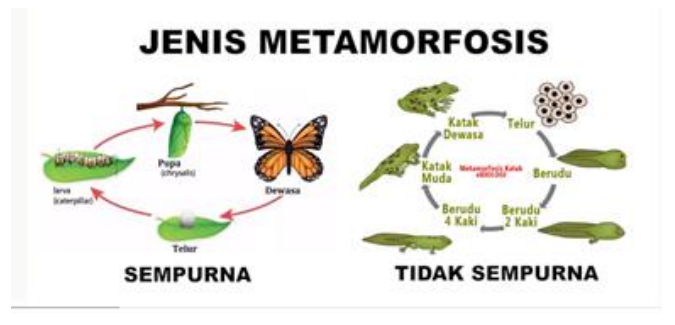

Gambar 4. Animasi Metamorfosis Kupu-kupu dan Katak (Sumber: www.youtube.com) 


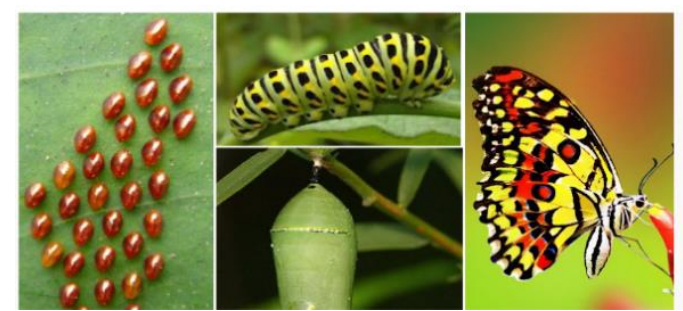

Gambar 5. Foto Metamorfosis Kupu-kupu

(Sumber: www.youtube.com/watch?v=6TYlVuREwvA)

Begitu pula yang terjadi pada perubahan bentuk katak yang seringkali mereka lihat di halaman rumah atau di sawah. Pada mulanya katak berasal dari telur yang bergerombol banyak selanjutnya berkembang menjadi berudu berkaki dua, kemudian berkembang menjadi berudu berkaki empat, lalu dilanjutkan berubah menjadi katak muda, dan terakhir berubah menjadi katak dewasa. Diharapkan dengan pemahaman ini para siswa/i lebih peduli dan mencitai terhadap kupu-kupu maupun katak di alam, sehingga mereka tidak merasa takut atau geli untuk memegangnya.

Contoh penyajian materi sains selanjutnya adalah mengenal anggota badan manusia dan fungsinya. Materi ini dikemas dalam bentuk animasi, gambar, dan audio/suara (Gambar 6). Tujuan penyampaian materi ini agar para siswa/i memahami dengan benar dan mampu mengingat tentang nama-nama dan fungsi dari anggota badan mereka masing-masing. Diharapkan dengan pemahaman ini akan meningkatkan rasa syukur para siswa/i atas ciptaan dan kebesaran Allah.

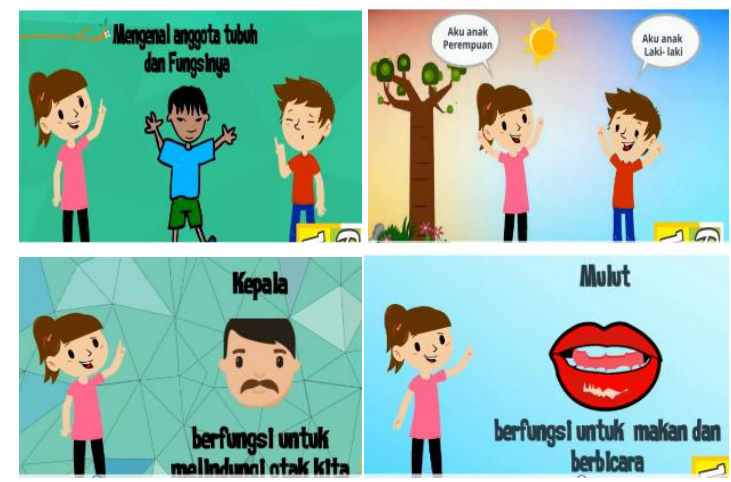

Gambar 6. Foto Anggota Badan

(Sumber: www.youtube.com/watch?v=aPpAOUVclog)

Contoh penyajian materi sains yang terakhir adalah mengenal beragam binatang yang hidup di air. Materi ini dikemas dalam bentuk animasi, gambar, dan 
audio/suara (Gambar 7). Tujuan penyampaian materi ini agar para siswa/i mengenal dengan benar dan mampu mengingat tentang nama-nama hewan yang hidup di air. Diharapkan dengan pemahaman ini akan mampu membangkitkan rasa sayang dan kepedulian mereka atas hewan-hewan air tersebut.
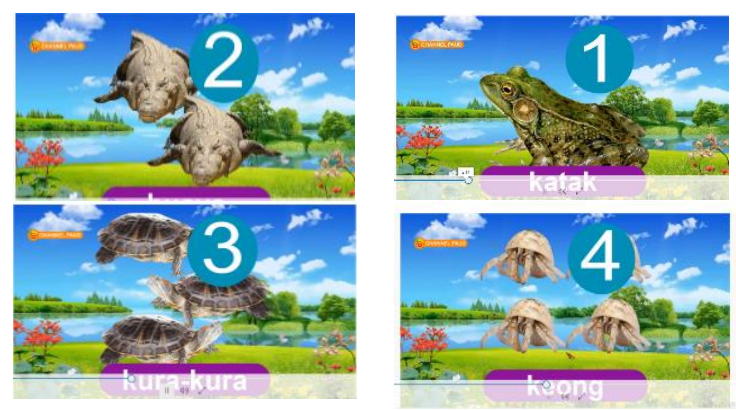

Gambar 7. Foto Beragam Binatang yang Hidup di Air

(Sumber: www.youtube.com/watch?v=aPpAOUVclog)

Kegiatan pendampingan terhadap para guru di ruang kelas dilakukan pada saat proses belajar mengajar sedang berlangsung. Kegiatan ini meliputi: cara pengoperasian laptop maupun materi sains yang disampaikan ke para siswa/i tidak menemui kendala maupun kesalahan. Tim PkM melakukan observasi secara langsung terhadap para guru dalam menyampaikan beberapa materi tersebut di atas.

Tidak berbeda dengan kegiatan pendampingan, aktivitas monitoring juga dilakukan pada saat proses pembelajaran sedang berlangsung di ruang kelas. Wawancara dengan para guru dilakukan untuk menggali hasil transfer pengetahuan tentang pelatihan pemanfaatan multimedia sehingga diharapkan dapat memberikan gambaran ketercapaian kegiatan PkM tersebut.

Kegiatan evaluasi dilakukan untuk mengukur keberhasilan, kendala, dan solusi untuk mengatasinya dari seluruh rangkaian kegiatan PkM. Aktivitas ini dilakukan pada saat kegiatan PkM telah berakhir. Evaluasi dilakukan terhadap bagaimana para guru mampu mengoperasikan laptop dan mampu menjelaskan materi-materi sains, sehingga siswa/i dengan mudah dapat menjelaskan kembali materi sains yang telah disampaikan para guru tersebut.

Terkait dengan penyampaian beberapa materi sains dalam proses pembelajaran, beberapa sarana penunjang yang dapat diberikan tim PkM Prodi Biologi, antara lain sejumlah perangkat pembelajaran multimedia (laptop, LCD, 
layar/screen, speaker, flashdisk, dan modem) kepada Yayasan Darul Ulum agar dapat dimanfaatkan lebih lanjut untuk mencerdaskan siswa/i TKQ Darul Ulum, Desa Jabon Mekar, Parung.

Beberapa kendala yang dihadapi Tim PkM dalam pelatihan ini adalah pembekalan materi dan praktek pelatihan bagi guru yang usianya tidak muda lagi agak sulit dan cukup lama untuk dapat memahaminya, namun begitu semagat belajar dan keingintahuan mereka terhadap pengetahuan baru cukup tinggi. Sebaliknya bagi guru-guru muda relatif cepat untuk menerima dan memahami transfer pengetahuan maupun praktek pelatihan tersebut. Kendala yang lain, karena kegiatan PkM ini dilaksanakan pada saat negara sedang dilanda wabah virus Covid-19 yang bersifat pandemi, sehingga relatif sulit untuk menghadirkan para siswa/i TKQ Darul Ulum masuk sekolah/dalam ruang kelas, sehingga secara umum berdampak kurang nyaman dalam pelaksanaan PkM ini.

Salah satu upaya untuk mengatasi kesulitan yang dihadapi oleh beberapa guru yang berusia sudah lanjut, yakni sebagian anggota tim PkM dengan tekun, sabar membimbing dan mengajari guru tersebut sampai benar-benar paham dan lancar mempraktekkannya. Adakalanya pada saat mereka lupa maka melalui telfon HP anggota tim PkM memandu dan mengajarinya sampai mereka mampu mengoperasikan seluruh perangkat multimedia. Solusi lainnya yang berkaitan dengan ketidaknyamanan pelaksanaan PkM ini dikarenakan situasi pandemi. Tim PkM mengusulkan dan berwacana apabila tim memiliki program sejenis dengan obyek yang berbeda maka pelaksanaan kegiatan PkM sebaiknya dilaksanakan pada saat negara telah pulih kembali normal agar diperoleh hasil yang optimal.
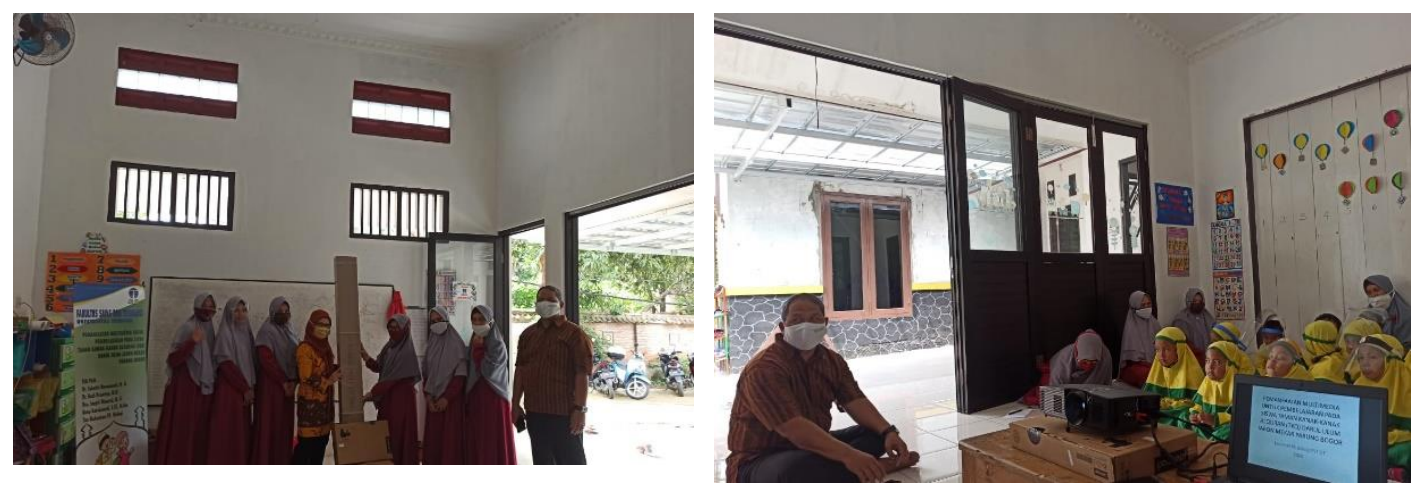

Gambar 8. Proses Monitoring Kegiatan PkM 


\section{KESIMPULAN}

Secara keseluruhan dari semua rangkaian proses kegiatan $\mathrm{PkM}$ tentang pemanfaatan multimedia untuk pembelajaran sains pada siswa TKQ Darul Ulum Jabon Mekar, Parung berjalan lancar dan menghasilkan luaran sesuai yang direncanakan tim PkM Prodi Biologi.

Berikut hasil pendataan tim $\mathrm{PkM}$ tentang sarana multimedia yang diperlukan untuk menunjang pembelajaran sains bagi siswa/i TKQ Darul Ulum berupa laptop, LCD, layar (screen), speaker, flashdisk, dan modem.

Kegiatan pelatihan telah dilaksanakan sesuai dengan metode pelaksanaan, sehingga proses pembelajaran materi sains di ruang kelas berjalan lancar dan normal, para guru dan siswa/i melakukan interaksi dua arah yang menjadikan terciptanya suasana belajar relatif ideal.

\section{DAFTAR PUSTAKA}

Asiah, S. (2012). Kemampuan Sains Anak Usia Dini melalui Pembelajaran dengan Keterampilan Proses dan Produk. Al-Fikrah: Jurnal Kependidikan Islam IAIN, 1, 26-36.

Dewi, A. C. (2012). Meningkatkan Kemampuan Sains Anak Usia Dini Melalui Pembelajaran Berbasis Ketrampilan Proses. Malih Peddas (Majalah Ilmiah Pendidikan Dasar), 1(2). https://doi.org/10.26877/malihpeddas.v1i2.301

Surasmi, W. A. (2016). Pemanfaatan Multimedia untuk Mendukung Kualitas Pembelajaran. Temu Ilmiah Nasional Guru (TING) VIII, November, 593607. http://repository.ut.ac.id/6555/1/TING2016ST2-32.pdf

Suyanto, S. (2014). Pengenalan Sains Untuk Anak Tk Dengan Pendekatan "Open Inquiry." Http://Staff.Uny.Ac.Id/Sites/Default/Files/PENGENALAN SAINS UNTUK ANAK TK(1).Pdf, 1-14. http://staff.uny.ac.id/sites/default/files/ PENGENALAN SAINS UNTUK ANAK TK(1).pdf

Utami, D. (2011). Animasi Dalam Pembelajaran. Majalah Ilmiah Pembelajaran, $7(1), 44-52$. 